\title{
Designing Investment Dispute Settlement à la Carte: Insights from Comparative Institutional Design Analysis
}

\author{
Stephan W. Schill \\ University of Amsterdam \\ S.W.B.Schill@uva.nl \\ Geraldo Vidigal \\ University of Amsterdam \\ g.vidigal@uva.nl
}

\begin{abstract}
The multilateral expression of the desire to reform investor-state dispute settlement (ISDS) at the United Nations Commission on International Trade Law (UNCITRAL) obscures the diverging preferences states have in respect of which future dispute settlement model to adopt. In order to garner broad acceptability, this article proposes that the reformed system could be designed as "dispute settlement à la carte", with a Multilateral Investment Court coexisting with other forms of dispute resolution under the umbrella of one multilateral institution. With a view to showing that such a system is feasible, this article draws on comparative institutional design analysis, that is, a comparative assessment of dispute settlement design features across different international dispute settlement systems. This approach helps to explore what institutional design features are a useful source of inspiration for a future investment dispute settlement system that preserves flexibility for states in the choice of their preferred means of adjudication, while safeguarding legal certainty and promoting coherence in investment dispute settlement.
\end{abstract}

\section{Keywords}

investment dispute settlement reform - United Nations Commission on International Trade Law (UNCITRAL) - comparative law - multilateral investment court - investorstate arbitration - multilateralism - international investment law 


\section{Introduction: Tabula Rasa in Investment Dispute Settlement Reform?}

Calls for investment law reform, long restricted to dissonant voices in academia and global politics, have gone mainstream. ${ }^{1}$ At the United Nations Commission on International Trade Law (UNCITRAL) a multilateral consensus has emerged on the desirability of reforming investor-state dispute settlement (ISDS). ${ }^{2}$ On this occasion, one may feel tempted to engage in the debates on reform with a spirit of tabula rasa, freed from any intellectual strictures imposed by preexisting mechanisms, procedures, and paradigms. Professor Sornarajah, a prominent critic of the existing system, has advocated for the need to "start anew in international investment law."3 In his view, "[w]iping the slate clean seems to be the only possible way forward."

If "starting anew" means thinking outside the box and independently of existing models and paradigms for investment dispute settlement, we agree with such an approach. If "starting anew," however, means that one should start entirely from scratch by engaging in free-floating intellectual imagination of ISDS reform, we consider that such an approach dismisses unnecessarily over a century of experiments and practice by states with international adjudication, including in respect of foreign investment disputes, not only by arbitrators, butalso by the International Court of Justice (ICJ) and its predecessor, the Permanent Court of International Justice (PCIJ). ${ }^{5}$ Intellectual imagination would also

1 From the recent scholarship, see e.g. Jean E. Kalicki and Anna Joubin-Bret (eds.), Reshaping the Investor-State Dispute Settlement System:Journeys for the 21st Century (Brill, 2015); C.L. Lim (ed.), Alternative Visions of the International Law on Foreign Investment: Essays in Honour of Muthucumaraswamy Sornarajah (CUP, 2016); Andreas Kulick (ed.), Reassertion of Control over the Investment Treaty Regime (CUP, 2016); Steffen Hindelang and Markus Krajewski (eds.), Shifting Paradigms in International Investment Law: More Balanced, Less Isolated, Increasingly Diversified (OUP, 2016); Simon Lester, "Rethinking the International Investment Law System", 49Journal of World Trade (2015), 211.

2 See United Nations Commission on International Trade Law (UnCiTRAL), "Draft Report of Working Group III (Investor-State Dispute Settlement Reform) on the Work of Its ThirtySixth Session", UN Doc. No. A/CN.9/964 (6 November 2018).

3 M. Sornarajah, "Starting Anew in International Investment Law", Columbia FDi Perspectives No. 74 (16 July 2012).

4 M. Sornarajah, Resistance and Change in the International Law on Foreign Investment (CUP, 2015), 408.

5 The law of state responsibility was systematized, for the first time, on the basis of jurisprudence of arbitral tribunals and claims commissions, in Dionisio Anzilotti, Teoria generale della responsabilità dello stato nel diritto internazionale (Lumachi, 1902). The Permanent Court of International Justice adjudicated on expropriation of foreign investments, for example, in Factory at Chorzow (Germany v. Poland), 1928, P.C.I.J., Series A, No. 17. On the 
make it difficult to find a yardstick for evaluating whether a proposal truly addresses certain concerns, what its intended and unintended consequences are likely to be, and what the prospects for acceptance of a certain model for dispute settlement by a large majority of states are. After all, if states are, as the consensus at UNCITRAL suggests, serious about resolving the concerns over consistency, coherence, and predictability in the current system of investorstate arbitration, there is hardly a way around agreeing on some form of multilateral solution. ${ }^{6}$

In this article, we argue that there is no need to start from scratch in order to develop concrete proposals for ISDS reform. Instead, we propose to adopt a methodology that we call "comparative institutional design analysis" in order to contemplate the variety of potential design features of a future system of investment dispute settlement and to inform the policy debates and the drafting of concrete reform proposals in the present UNCITRAL process. Comparative institutional design analysis involves drawing on the trove of experiences accumulated not only in the international investment regime but in international dispute settlement more generally, with respect to questions of dispute settlement design. ${ }^{7}$ This method does not seek to answer the question of how first order principles - such as the rule of law, democracy, the protection of human rights, or the promotion of sustainable development-should inform the reform of ISDS. ${ }^{8}$ Different from much of the use of comparative methodology

jurisprudence of the International Court of Justice in foreign investment matters, see Alain Pellet, "The Case Law of the ICJ in Investment Arbitration", 28 ICSID Review-FILJ (2013), 223.

6 Martti Koskenniemi, hardly a cheerleader for ISDs, has aptly pointed out that "[t]he real problem faced by Sornarajah and many other critics of investment arbitration is that there is no clear base from which alternatives could be proposed." See Martti Koskenniemi, "It's Not the Cases, It's the System", 18 Journal of World Investment \& Trade (2017), 343, 353.

7 Our method is related to what Sergio Puig and Gregory Shaffer call "comparative institutional analysis". See Sergio Puig and Gregory Shaffer, "Imperfect Alternatives: Institutional Choice and the Reform of Investment Law", 112 American Journal of International Law (2018), 361, 379-383. Comparative institutional design analysis differs in two important regards from the method adopted by Puig and Shaffer. First, we limit our understanding of "institution" to actually existing bodies or mechanisms for dispute settlement under international law and do not use the wider notion of "institution" that encompasses market mechanisms and political mechanisms. Second, the purpose for which we draw on comparative institutional analysis differs from that of Puig and Shaffer. While they use this method to facilitate institutional choice between a fixed set of alternatives by showing which biases and trade-offs each alternative involves, we use comparative institutional design analysis as a method to generate and evaluate alternatives for institutional design, and to show how proposed alternatives fit with existing design features of international dispute settlement.

8 For such approaches, see e.g. United Nations Conference on Trade and Development (UNCTAD), Investment Policy Framework for Sustainable Development (United Nations, 2015); Stephan W. Schill, “Reforming Investor-State Dispute Settlement: A (Comparative and 
in international law, it also does not consist of the distillation of general principles of law. ${ }^{9}$ Instead, comparative institutional design analysis consists of analyzing the design features of other international dispute settlement mechanisms and bodies in order to draw inspiration for developing models for dispute settlement design and, on this basis, to inform the current debates about ISDS reform. Furthermore, while we agree that paying attention to context and assessing how well a certain design feature that exists in another dispute settlement context may also work in investment dispute settlement are essential parts of any comparative exercise, we do not use comparative institutional design analysis to argue for a legal transplant, in the sense of trying to embed features from one system into another existing system. Rather, we use comparative analysis for developing the design features of an entirely new institutional context. The purpose of comparative institutional design analysis is to answer the practical question of how concrete reform proposals could possibly be designed and what institutional features they could have. It is an exploratory method for developing a basis for treaty negotiation de lege ferenda, not a means to determine conclusively which of the options available is preferable. This will depend, not least, on the future negotiations between the different actors involved.

Instead of developing comparative institutional design analysis as a method in the abstract, we show how it operates in respect of a concrete reform proposal that we have made recently as part of the current ISDS reform debate. We have proposed the establishment of a Multilateral Institution for Dispute Settlement on Investment (MIDSI) which would allow states to maintain their strongly entrenched preferences for certain modes of dispute settlement (reformed investor-state arbitration, inter-state arbitration, establishment of a permanent investment court, strengthening of domestic remedies), while integrating these approaches under one multilateral institutional framework..$^{10}$ In the present article, we show that engaging in a comparative, cross-regime analysis of how other systems of dispute settlement under international law function allows us (and hopefully the negotiators) to explore the wealth of

International) Constitutional Framework", 20 Journal of International Economic Law (2017), 649; Marie-Claire Cordonier Segger, Markus W. Gehring and Andrew Paul Newcombe (eds.), Sustainable Development in World Investment Law (Kluwer, 2011); Till Patrik Holterhus, The Law Behind Rule of Law Transfers: On Rule Based Interactions of Legal Orders in a Globalized World (Nomos, 2019).

9 On this use of comparative law in international law, see Jaye Ellis, "General Principles and Comparative Law”, 22 European Journal of International Law (2011), 949.

10 Stephan W. Schill and Geraldo Vidigal, Cutting the Gordian Knot: Investment Dispute Settlement à la Carte (ICTSD, 2018). 
potential design features for the future legal regime for investment dispute settlement and contribute to designing MIDSI as a single multilateral institution that allows states to adhere to their preferred mode for dispute settlement, while exhibiting sufficient centripetal pull to keep the negative effects of fragmentation to a minimum.

Part 2 presents, in a nutshell, the proposal for the creation of MIDSI. Part 3 then shows how comparative institutional design analysis supports the flexibility we envisage for MIDSI with respect to key aspects of its institutional design. This flexibility is not unprecedented, but rather reflects the diversity and flexibility that already exists in international adjudication. Part 4, in turn, illustrates how comparative institutional design analysis can be used to develop design features of MIDSI that help prevent fragmentation and contribute to more consistency and coherence in respect of those norms that are shared across different investment dispute settlement mechanisms and the common principles reflected in the multitude of bilateral, regional, and sectoral international investment agreements (IIAS), even though MIDSI would not require states to opt for only one mode of settling investment disputes. Part 5 closes by addressing how comparative institutional design analysis does not need to be limited to helping improve adjudicatory mechanisms, but can help envision functions for MIDSI that are unrelated to dispute resolution in the strict sense.

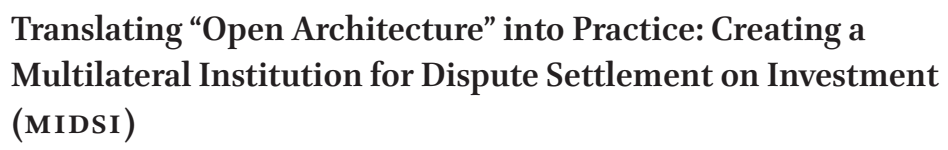

One of the core concerns with present-day IsDs identified in the current UNCITRAL process relates to the lack of consistency, coherence, predictability, and correctness of arbitral rulings. ${ }^{11}$ This concern stems not only from the existence of more than 3,000 differently worded bilateral, sectoral, and regional investment agreements and investment chapters in free trade agreements, but is above all a reflection of the institutional structure of ISDS, where disputes are settled by arbitral tribunals on a one-off basis under a variety of institutional rules with only limited possibilities for substantive review. As a result, a number of inconsistent and incoherent decisions by different arbitral tribunals have come about on issues of jurisdiction and admissibility, and as regards

11 See UNCITRAL, supra note 2, paras. 40, 53, 63. 
the interpretation and application of similar, or even identical, substantive standards of treatment. ${ }^{12}$

To create more consistency, coherence, and predictability across the entire investment treaty regime, further institutionalization seems to be called for. One way to achieve this would be to adopt the proposal made by the European Union (EU) and its Member States in the context of the current UNCITRAL process to establish a "standing mechanism for the settlement of investment disputes." ${ }^{13}$ If structured to allow ISDS proceedings under existing IIAs to come under the umbrella of the new institution, ${ }^{14}$ such a "multilateral investment court" (MIC) would indeed seem capable of addressing most, if not all, the concerns identified in the UNCITRAL process: it would ensure greater coherence and consistency and be more independent and cost-effective than any alternative. ${ }^{15}$

At the same time, it is difficult to imagine that the EU's model for ISDS will be universally accepted. Despite converging ideas regarding many procedural features, such as increased transparency, enhancing independence and impartiality of dispute resolvers, increasing possibilities for early dismissal of unmeritorious claims, and ensuring state control and avoiding multiple proceedings, the preferences of other parties about the path the reform process

12 For an analysis of the structural reasons for inconsistencies, see Stephan W. Schill, The Multilateralization of International Investment Law (CUP, 2009), 281-293. See also Frank J. Garcia et al., "Reforming the International Investment Regime: Lessons from International Trade Law", 18 Journal of International Economic Law (2015), 861.

13 European Commission, "Submission of the European Union and its Member States to UNCITRAL Working Group III" (18 January 2019), http://trade.ec.europa.eu/doclib/ html/157631.htm, accessed 5 March 2019 (reproduced in UnCitral, UN Doc. No. A/ CN.9/WG.III/WP.159/Add.1 (24 January 2019)). On the mandate of the Commission, see Council of the European Union, "Negotiating Directives for a Convention Establishing a Multilateral Court for the Settlement of Investment Disputes" (EU Doc. No. 12981/17 ADD 1) (1 March 2018). See Catharine Titi, “The European Union's Proposal for an International Investment Court: Significance, Innovations and Challenges Ahead", 14(1) Transnational Dispute Management (2017); Marco Bronckers, "Is Investor-State Dispute Settlement (ISDS) Superior to Litigation Before Domestic Courts? An EU View on Bilateral Trade Agreements", 18 Journal of International Economic Law (2015), 655.

14 This could be achieved through an opt-in mechanism similar to how the Mauritius Convention extended the UnCitral Rules on Transparency to old iras. See Commission, supra note 13, paras. 11-37. See further on the opt-in mechanism Gabrielle KaufmannKohler and Michele Potestà, Can the Mauritius Convention Serve as a Model for the Reform of Investor-State Arbitration in Connection with the Introduction of a Permanent Investment Tribunal or an Appeal Mechanism? Analysis and Roadmap (cIDs-Geneva Center for International Dispute Settlement, 2016).

15 See Commission, supra note 13 , paras. $40-56$. 
should take in terms of institutional design diverge starkly from the EU's proposal. ${ }^{16}$ Several states (including the United States and Japan) favour reforming investor-state arbitration incrementally instead of creating a permanent court, as exemplified by the Agreement for Comprehensive and Progressive TransPacific Partnership (СРTP P). ${ }^{17}$ Other states, like India, express a strong preference for a larger role for domestic courts, even suggesting the reintroduction of the exhaustion of local remedies; ${ }^{18}$ and yet other states, in particular Brazil, have been acting to establish inter-state (instead of investor-state) arbitration as the preferred means of settling investment disputes. ${ }^{19}$ China, which has recently entered into IIAs featuring both classical and reformed ISDs, ${ }^{20}$ and which is developing a parallel system for investment dispute settlement through the Belt and Road Initiative, ${ }^{21}$ has only recently engaged directly with the debates over ISDS reform, proposing an arbitration system that is coupled with a "permanent appellate mechanism". ${ }^{22}$

Given these competing reform proposals, it would be tempting to seek multilateral consensus by opening a debate about the pros and cons of each model and proposing further deliberations and negotiations until a large majority of states are able to agree on one model of investment dispute settlement. ${ }^{23}$

16 See further Schill and Vidigal, supra note 10; Anthea Roberts, "Incremental, Systemic, and Paradigmatic Reform of Investor-State Arbitration”, 112 American Journal of International Law (2018), 410. For the proposals submitted to UnCITRAL Working Groups III, see https://uncitral.un.org/en/working_groups/3/investor-state (20 July 2019).

17 Comprehensive and Progressive Agreement for Trans-Pacific Partnership, signed 8 March 2018, entered into force 30 December 2018 (СРТРP). The СРтРP is the follow-up agreement concluded by the states that remained committed to the Trans-Pacific Partnership (ТРP), which was signed on 4 February 2016, after the U.S. withdrawal following the election of Donald Trump as President of the United States. The CPTPP incorporates the text of TPP, which was heavily influenced by U.S. positions.

18 See the Model Text for the Indian Bilateral Investment Treaty (January 2016), http://investmentpolicyhub.unctad.org/Download/TreatyFile/356o, accessed 5 March 2019.

19 Geraldo Vidigal and Beatriz Stevens, "Brazil's New Model of Dispute Settlement for Investment: Return to the Past or Alternative for the Future?", 19 Journal of World Investment \& Trade (2018), 475.

20 See Hongling Ning and Tong Qi, "Multilateral Investment Court: The Gap Between the EU and China”, 4 Chinese Journal of Global Governance (2018), 154.

21 Huiping Chen, "China's Innovative ISDS Mechanisms and Their Implications", 112 AJIL Unbound (2018), 207; Sienho Yee, "Dispute Settlement on the Belt and Road: Ideas on System, Spirit and Style", 17 Chinese Journal of International Law (2018), 907.

22 Uncitral Working Group III, "Possible Reform of Investor-State Dispute Settlement (ISDS) - Submission from the Government of China” (19 July 2019), UN Doc. No. A/CN.9/ WG.III/WP.177 (translation by the UNCITRAL Secretariat), 4.

For one such analysis, see Puig and Schaffer, supra note 7. 
Yet, it is unlikely that one model ultimately will find such universal support, as the different positions on investment dispute settlement design reflect largely entrenched political stances, with room for compromise consequently being very limited. ${ }^{24}$ The EU, for example, has been unable to convince Japan in recent negotiations of a bilateral trade and investment agreement to adhere to its MIC proposal. ${ }^{25}$ Similarly, it seems unlikely that India, which in 2016 terminated 58 IIAs featuring traditional ISDs, ${ }^{26}$ or Brazil, which has never ratified IIAs containing traditional ISDS, ${ }^{27}$ would have a change of heart and either adhere to incrementally reformed investment arbitration of the type contained in the СРтPP or adhere to the MIC.

What should be avoided, however, is a situation in which every party seeks to promote, through bilateral agreements (or "minilateral" ones among only a handful of parties), its own model, thereby threatening a key objective of the current reform process, namely to enhance consistency, coherence, and predictability in investment adjudication more generally. This objective, in our view, can be achieved properly only through multilateral solutions.

The question then becomes whether a multilateral solution, on the one hand, and flexibility in investment dispute settlement, on the other hand, are mutually exclusive. In our view, this is not the case. Instead, the way to ensure the widest possible participation of states in a multilateral reform of ISDS is to make flexibility in dispute settlement the cornerstone of any newly established multilateral legal framework. For this reason, we have proposed adding to UNCITRAL's agenda discussions on the establishment of MIDSI, a multilateral institution that could provide an umbrella for dispute settlement options that participating members could chose from "à la carte". ${ }^{28}$ This would connect to the idea of an "open architecture" for the future of investment dispute settlement that has already been brought into play, inter alia, by

24 Catharine Titi, "Who's Afraid of Reform? Beware the Risk of Fragmentation", 112 AJIL Unbound (2018), 232. The existence of mutually incompatible positions is not new. See Wenhua Shan, "From North-South Divide to Private-Public Debate: Revival of the Calvo Doctrine and the Changing Landscape in International Investment Law", 27 Northwestern Journal of International Law \& Business (2007), 631.

25 European Commission, "EU-Japan Investment Negotiations", Press Release (11 July 2018).

26 Akshat Agharwal, "Rethinking the Regulation of International Foreign Investment: Recent Developments in Brazil, South Africa and India”, 10 Indian Journal of International Economic Law (2019), 1, 11.

27 Vidigal and Stevens, supra note 19, 485.

28 Schill and Vidigal, supra note 10. 
the EU. ${ }^{29}$ Following this idea, MIDSI would not feature any one system of compulsory jurisdiction, but would allow parties to the regime to opt for the dispute settlement mechanism of their choice. MIDSI could include, as one of its pillars, a fully-fledged MIC, allowing the EU and its Member States to put into practice their project of establishing a permanent investment court. Another pillar could administer inter-state arbitrations, allowing Brazil and its followers ${ }^{30}$ to participate in the creation and operation of MIDSI, and yet another pillar could administer (reformed) investor-state arbitrations, with or without using the MIC as an appeals or annulment body, thus allowing those states that reject the idea of a standing court to participate in a truly multilateral framework. Access to MIDSI could also be set up to allow states flexibility in respect of prior recourses under domestic law.

Furthermore, on an opt-in basis, the MIC pillar of MIDSI could perform different roles for different states. We would envision it as a permanent body whose members are elected by a multilateral assembly of states parties to the MIDSI Agreement, independently of the use states make of the MIC for settling their investment disputes. The MIC could serve as a fully-fledged investment court for some states, and as an appeals body or annulment institution for others. Even for those states that do not opt to use it for adjudication, the MIC could carry out systemic functions, such as deciding on challenges to arbitrators or rendering provisional measures before an arbitral tribunal is constituted. Finally, the MIC could perform functions that are currently absent in the investment law context, such as issuing advisory opinions or rulings on preliminary references by arbitral tribunals or even national courts, thus providing clarity on specific points of interpretation and resolving inconsistencies that have arisen under the current system.

Establishing MIDSI in this fashion could create a multilateral structure for investment adjudication and help achieve one of the core objectives of ISDS reform, as identified in the current UNCITRAL process: to create more consistency, coherence, and predictability in investment dispute settlement. ${ }^{31}$ Certainly, the parallel existence of different dispute settlement options, coupled with the governing law of investment disputes remaining enshrined in domestic law and a multitude of bilateral, regional, and sectoral IIAs, may not look like much of an advance in terms of coherence and consistency as compared to the existing system of investor-state arbitration. Yet, we would posit

29 Commission, supra note 13, para. 39. See also Roberts, supra note 16, 431-432; Puig and Shaffer, supra note 7,409 .

30 See Brazil's submission to UnCitral Working Group III: Investor-State Dispute Settlement Reform of 11 June 2019, https://undocs.org/en/A/CN.9/WG.III/WP.171, accessed 22 July 2019. 
that the existence of a single multilateral institution that serves as an umbrella for flexible dispute settlement holds greater potential for future convergence, and could exercise a greater degree of centripetal force, than a system that offers the same flexibility but without a multilateral institution backing it up and administering it.

One important concern, however, is whether a MIDSI having this format is at all a realistic endeavour and could find sufficiently wide support from states. One may also question the consequences the establishment of such an institution could have, and whether it would address the concerns identified with respect to present-day ISDS. Comparative institutional design analysis, that is, looking at design solutions found in other international courts and tribunals, in our view, helps to shed light on the possibilities for, and limits of, institutional design and is able to lend support to the core design features of the MIDSI model we sketched out in this section. As we will illustrate in the next two sections, the design we envision for MIDSI draws on features that are present in other systems of international dispute settlement; it combines flexibility in dispute settlement design with certain elements of defragmentation that are able to exercise a pull towards future convergence in international investment law more generally.

\section{$3 \quad$ Flexibility in International Dispute Settlement Design}

Under international law, states enjoy broad freedom with respect to the extent to which they undertake commitments and submit to adjudication. Some agreements, in particular those establishing highly institutionalized organizations, such as the World Trade Organization (wTO), the EU, or the Council of Europe, are based on the idea of a single "membership package". This includes acceptance not only of a set of substantive obligations, but also submission to the compulsory jurisdiction of an institutionalized dispute settlement mechanism. ${ }^{32}$

In the broader landscape of international law, however, these agreements remain the exception. Indeed, comparative institutional design analysis shows that most international dispute settlement systems are characterized

32 Celso Lafer, The World Trade Organization Dispute Settlement System (Gilberto Amado Memorial Lecture) (United Nations, 1996); N. David Palmeter, The WTO as a Legal System: Essays on International Trade Law and Policy (Cameron May, 2003); Morten Rasmussen, "Revolutionizing European Law: A History of the Van Gend en Loos Judgment", 12 International Journal of Constitutional Law (2014), 136; Council of Europe, Resolution 1031 (1994) on the Honouring of Commitments Entered into by Member States when Joining the Council of Europe, para. 9 . 
by a significant degree of flexibility. The proposal of MIDSI we outlined above would take that flexibility as one of its core organizing principles in order to help unite states under one multilateral institution for the settlement of investment disputes. Under this approach, the MIDsi Agreement can (a) leave it to each party to determine whether to accept compulsory jurisdiction in international investment dispute settlement at all (see Section 3.1) and (b) offer parties a choice among modes of dispute settlement (see Section 3.2). To accommodate different preferences, it can also (c) provide flexibility to the parties with respect to core aspects of dispute settlement, including in particular on standing, the role of domestic courts, and remedies (see Section 3.3).

\subsection{Decoupling Membership and Jurisdiction}

Being a party to an agreement that establishes an adjudicative mechanism, or even being a member of an organization that has its own institutional dispute resolution system, does not necessarily mean accepting the compulsory jurisdiction of an international court or tribunal. Instead, membership in the organization and jurisdiction of its adjudication system can be designed as separate from each other. This is most clearly the case in the United Nations (UN) system. The Charter of the United Nations (UN Charter) describes the ICJ as the "principal judicial organ of the United Nations" 33 and makes all UN Members parties to the ICJ Statute. ${ }^{34}$ However, it does not endow the Court with compulsory jurisdiction over Members' disputes. Instead, Article 36(1) of the ICJ Statute provides the ICJ with jurisdiction solely over "cases which the parties refer to it" and "matters specially provided for ... in treaties and conventions in force." And, while Article 36(2) permits states to declare ex ante their general consent to the jurisdiction of the Court, states are also permitted to tailor their declarations and exclude issues that they would not like to see adjudicated. ${ }^{35}$

Similarly, the Convention on the Settlement of Investment Disputes between States and Nationals of Other States (ICSID Convention) clarifies that

33 Charter of the United Nations, signed 26 June 1945, entered into force 24 October 1945, 1 UNTS XVI, Article 92.

34 Ibid., Article 93(1).

35 See Statute of the International Court of Justice, Annex to the Charter of the United Nations, supra note 33, 33 UNTS 993 (ICJ Statute), Article 36(3). The practice of issuing declarations with reservations of various types has been accepted by the Court. See e.g. Military and Paramilitary Activities in and against Nicaragua (Nicaragua v. United States of America), Jurisdiction and Admissibility, Judgment, I.C.J. Reports 1984, p. 392. See Stanimir A. Alexandrov, "The Compulsory Jurisdiction of the International Court of Justice: How Compulsory Is It?", 5 Chinese Journal of International Law (2006), 29. 
entering into the Convention does not entail "any obligation to submit any particular dispute to conciliation or arbitration." ${ }^{36}$ Article 25 of the Convention provides ICSID with jurisdiction over disputes which the "parties to the dispute consent in writing to submit to the Centre." Furthermore, Article 25(4) permits each party to notify ICSID of "the class or classes of disputes which it would or would not consider submitting to the jurisdiction of the Centre." This notification, which does not constitute consent to jurisdiction, allows states to actively consider, and indicate to each other, what type of disputes they are willing to submit to adjudication in the future. ${ }^{37}$

Another case in point is the Organization of American States (OAS), with its two-tiered system for the protection of human rights. An administrative body - the Inter-American Commission of Human Rights - oversees compliance with human rights by all oAs Members, while the Inter-American Court of Human Rights (IACtHR) operates only on the basis of separate consent, exercising jurisdiction solely over OAS states that (i) are parties to the American Convention on Human Rights, and (ii) make an affirmative decision to submit to the Court's jurisdiction, whether fully or partially. ${ }^{38}$ Some oAs Members, like the United States and Canada, have never joined the Convention. Others (Venezuela and Trinidad and Tobago) have denounced it after initially having accepted the IACtHR's jurisdiction. ${ }^{39}$

Thus, one option open for drafters of a MIDsi Agreement is to decouple participation in the institution itself from submission to the jurisdiction of any of the dispute settlement options it offers. As provided for in the UN Charter, parties would be able to choose among several "peaceful means" of dispute settlement, including "negotiation, enquiry, mediation, conciliation, arbitration, judicial settlement, resort to regional agencies or arrangements." ${ }^{" 0}$ While

36 Convention on the Settlement of Investment Disputes between States and Nationals of Other States, adopted 18 March 1965, entered into force 14 October 1966, 575 UNTS 159 (ICSID Convention), Preamble, 7 th recital.

37 See Christoph Schreuer et al., ICSID Convention: A Commentary (2nd edition, CUP, 2009), Art. 25, paras. $921 \mathrm{ff}$.

38 American Convention on Human Rights, adopted 22 November 1969, entered into force 18 July 1978, 1144 UnTs 123, Articles 33, 62(1), 62(2). The Inter-American Court of Human Rights (like its European counterpart) considers most reservations to be incompatible with the object and purpose of the Convention. See Ineta Ziemele and Lāsma Liede, "Reservations to Human Rights Treaties: From Draft Guideline 3.1.12 to Guideline 3.1.5.6", 24 European Journal of International Law (2013), 1135.

39 OAs, American Convention on Human Rights 'Pact of San Jose, Costa Rica' - Signatories and Ratifications, www.oas.org/dil/treaties_B-32_American_Convention_on_Human_Rights_ sign.htm, accessed 2 August 2019 .

40 Charter of the United Nations, Article 33(1). 
providing freedom to states to accept the jurisdiction of different adjudicators and different procedural rules, the MIDsi Agreement could provide an institutional framework for the settlement of investment disputes. Like the ICSID Convention, it could establish basic rules on jurisdiction, ${ }^{41}$ but require consent itself to be expressed in separate agreements.

\subsection{Choice of Modes of Adjudication}

Another way to provide for flexibility for dispute settlement under the MIDSI Agreement would be to allow parties to determine which mode of dispute settlement to accept in principle, and to combine adjudication by a permanent court with the parallel possibility to opt for arbitration. This flexibility in the choice of modes of adjudication is inspired most evidently by the approach to dispute settlement under the United Nations Convention on the Law of the Sea (UNCLOS). ${ }^{42}$ Pursuant to UNCLOS Article $287(1$ ), states signing, ratifying, or acceding to UNCLOS are "free to choose" among different institutional arrangements for the settlement of disputes concerning UNCLOS. They may choose to submit disputes concerning UNCLOS to the International Tribunal for the Law of the Sea (ITLOS), to the ICJ, or to an arbitral tribunal under UNCLOS Annex VII. ${ }^{43}$

While UNCLOS parties may select a preferred form of adjudication, one of them necessarily has compulsory jurisdiction. UNCLOS Article $287(3)-(5)$ provides that, in case the parties to a dispute have made matching declarations selecting the same mode of adjudication, this mode becomes compulsory between them (without preventing them, however, from agreeing ad hoc to pursue dispute settlement under a different mechanism). In the absence of matching declarations, a default mechanism - arbitration under UNCLOS Annex VII remains compulsory. Annex viI sets up rules to prevent a respondent from undermining the arbitration procedure by not cooperating in the composition of the tribunal.

A degree of flexibility exists even within the wTo dispute settlement system. The wTo Dispute Settlement Understanding (DSU) in principle requires wTO

\footnotetext{
41 See ICSID Convention, Article 25(1), which provides that " $[\mathrm{w}]$ hen the parties have given their consent, no party may withdraw its consent unilaterally".

42 United Nations Convention on the Law of the Sea, adopted 10 December 1982, entered into force 16 November 1994, 1833 UNTS 397 (UNCLOS).

43 UNCLOS, Article $287(\mathrm{a})-(\mathrm{c})$. Article 287 (d) permits parties to empower specific kinds of tribunals, constituted under Annex viII, for specific kinds of disputes. For an instructive overview over the design features of dispute settlement under UnCLOS, see Alan E. Boyle, "Dispute Settlement and the Law of the Sea Convention: Problems of Fragmentation and Jurisdiction", 46 International \& Comparative Law Quarterly (1997), 37.
} 
Members that seek redress for violations of wTо law to "have recourse to, and abide by, the rules and procedures" it establishes, involving an assessment of the dispute by a wто panel and a possible appeal to the WTO Appellate Body. ${ }^{44}$ At the same time, Article 25 of the DSU establishes a specific mechanism for "[e]xpeditious arbitration within the $\mathrm{WTO}^{\text {"45 }}$ as an alternative means of dispute settlement. The DSU thus combines an institutionalized and compulsory dispute settlement procedure with the possibility, open to consenting parties, of resort to arbitration. The wTо Appellate Body has referred to this mechanism, as well as to good offices, conciliation and mediation, as "consensual means of dispute resolution" that are available to consenting parties as "alternatives to compulsory adjudication" by wTo panels and the Appellate Body. ${ }^{46}$ While the wTO is often thought of as providing for a single adjudication mechanism, therefore, the DSU itself establishes an alternative for parties wishing to settle their disputes relating to wTо law.

If implemented within MIDSI, the à la carte model would permit broader flexibility, with the parallel availability under the MIDsi Agreement of different modes of adjudication, without necessarily establishing a means that every party must adhere to (as the WTO DSU does) or even a default procedure (as UNCLOS does). The MIDSI Agreement may thus establish a MIC, while allowing parties to choose other means of dispute settlement, including not only investor-state arbitration, but also inter-state arbitration, which could both be administered by MIDSI. The MIDsi Agreement may permit (but would not need to require) parties to declare unilaterally that they consent to submit to adjudication under a certain mode of dispute settlement, regardless of the position taken by the investor's home state; it may establish a default mechanism, while allowing parties to agree on alternative modes of dispute settlement; or it may simply model itself on the ICSID Convention, establishing a framework for the exercise of jurisdiction, while permitting parties to determine the extent of their submission to this jurisdiction independently from adhering to the Convention. ${ }^{47}$

\footnotetext{
44 Understanding on Rules and Procedures Governing the Settlement of Disputes (Agreement Establishing the World Trade Organization, Annex 2), signed 15 April 1994, entered into force 1 January 1995, 1869 UNTS 401 (DSU), Article 23(1).

45 Ibid., Article 25(1).

46 Appellate Body Report, US/Canada-Continued Suspension, adopted 14 November 2008 (WT/DS320/AB/R, WT/DS $321 / \mathrm{AB} / \mathrm{R})$, para. 340. Good offices, conciliation, and mediation are governed by Article 5 of the DSU.

47 ICsid Convention, Preamble, 7 th recital.
} 

Remedies

Besides permitting parties to determine their preferred mode to settle investment disputes, the MIDs I Agreement may also provide parties with flexibility regarding other core organizational rules. Comparative institutional design analysis reveals a wealth of possibilities in respect of three key issues over which major proponents of reform have adopted divergent views: (i) the question of who has standing to bring claims; (ii) the relationship between international adjudication and domestic courts; and (iii) the remedies available in investment dispute resolution.

With respect to standing, there is divergence between states that favour ISDS and those that prefer limiting investment dispute settlement to the state-to-state level. Permitting individuals and companies harmed by violations to bring cases before an adjudicator, without requiring the support or approval of their state of nationality, should in principle lead to a higher rate of enforcement. ${ }^{48}$ At the same time, state-to-state adjudication systems may be successful under the right circumstances. State-to-state adjudication operates successfully in the WTO dispute settlement system, with economic agents often operating in conjunction with governments. ${ }^{49}$ Under UNCLOS, state-tostate adjudication also remains the rule. However, procedures for the prompt release of detained vessels have come to be dominated de facto by private litigants. This is due in part to the possibility of seizing ITLOs "on behalf of" the flag State, ${ }^{50}$ which has led to a practice by which states initiate proceedings, and are represented by their agents, but in which the bulk of the argumentation is carried out by private attorneys retained by the affected ship-owner. ${ }^{51}$

In investment dispute settlement, inter-state adjudication regularly exists alongside investor-state arbitration in IIAs. While Is Ds has been used far more

48 See Alan O. Sykes, "Public versus Private Enforcement of International Economic Law: Standing and Remedy", 34Journal of Legal Studies (2005), 631.

49 Vidigal and Stevens, supra note 19, 518. See also Gregory Shaffer et al., "The Trials of Winning at the WTO: What Lies Behind Brazil's Success", 41 Cornell International Law Journal (2008), 383 .

50 Prompt release procedures may be brought not only "by" the flag state of a vessel but also "on behalf of" the flag state (UNCLOS, Article 292(2)). See Seline Trevisanut, "Twenty Years of Prompt Release of Vessels: Admissibility, Jurisdiction, and Recent Trends", 48 Ocean Development \& International Law (2017), 300.

51 See a reference to this practice by Judge ad hoc Shearer in ITLos, "Volga" (Russian Federationv. Australia), Prompt Release, Judgment (2 December 2002), Dissenting Opinion of Judge ad hoc Shearer, ITLOS Reports 2002, 66, 72. See further Vidigal and Stevens, supra note 19,510 . 
vastly, inter-state arbitration has also taken place a few times. ${ }^{52}$ Similarly, in the case of human rights courts, private (and institutional) enforcers tend to initiate the vast majority of cases, but states remain able to bring disputes to adjudication. The European Court of Human Rights has adjudicated a few inter-state disputes, ${ }^{53}$ and both the Inter-American Court ${ }^{54}$ and the African Court on Human and Peoples' Rights can also be seized by states against other states. ${ }^{55}$ Adopting a similar system in the MIDSI Agreement, permitting state parties to choose to accept state-to-state dispute settlement, to permit investor-state claims, or both, would provide states with flexibility to adhere to the Agreement without necessarily pre-committing to fixed rules on standing. It would also not be unusual given that other systems of international adjudication combine inter-state and mixed (private-public) dispute resolution.

Another contentious point that can be subject to flexible tailoring under a MIDSI Agreement is the relationship between international and domestic adjudication. The requirement of exhaustion of local remedies, which makes international courts an instance of last resort when local courts fail to provide remedies, is waived in principle under the ICSID Convention and is absent in most IIAs, which led both ICSID and non-ICSID arbitral tribunals to hold that, as a rule, the exhaustion of local remedies is not required in investment arbitration. ${ }^{56}$ This allows investors immediately to resort to ISDs instead of domestic courts, rather than after, and in addition to, seizing domestic courts. However, even under the ICSID Convention, parties remain free to require the exhaustion of local administrative or judicial remedies as a condition of their consent to arbitration. ${ }^{57} \mathrm{~A}$ similar provision may be incorporated into the MIDSI Agreement. While parties may always offer more advantageous conditions by agreement, states like India, which favour local remedies over

$5^{2}$ Italy v. Cuba, Final Award (15 January 2008). See Rodrigo Polanco, The Return of the Home State to Investor-State Disputes: Bringing Back Diplomatic Protection? (CUP, 2019), 265-268.

53 European Court of Human Rights, Cyprus v. Turkey, App. No. 25781/94, Judgment (10 May 2001); Republic of Ireland $v$. The United Kingdom, App. No. 5310/71, Judgment (18 January 1978).

54 American Convention on Human Rights, Article 61(1).

55 Protocol to the African Charter on Human and Peoples' Rights on the Establishment of an African Court on Human and Peoples' Rights, adopted 10 June 1998, entered into force 25 January 2004, Article 5(1). The Court can also be seized by African Intergovernmental Organizations.

$5^{6}$ Christoph Schreuer, "Calvo's Grandchildren: The Return of Local Remedies in Investment Arbitration", 4 Law and Practice of International Courts and Tribunals (2005), 1, 1-2.

57 ICsid Convention, Article 26. 
international adjudication, could require that investors exhaust, or actively pursue, local remedies prior to resorting to adjudication. ${ }^{58}$

There may be need under a MIDSI Agreement for flexibility with respect to remedies as well. Some states, most clearly Brazil, seek to put an end to the practice of monetary awards, and instead would prefer an international dispute settlement mechanism to identify violations and require states to cease them. By contrast, other states, including the United States, and the EU in their recent IIA practice, explicitly discourage investment tribunals from awarding non-monetary remedies, providing that, even if tribunals demand performance, states retain the right to provide monetary compensation rather than change their conduct or restitute or restore property rights. ${ }^{59}$ The MIDSI Agreement may therefore allow states to determine, through their declarations and agreements, their preferred remedies in investment dispute settlement.

In conclusion, the MIDSI Agreement may provide a multilateral institutional framework for adjudication while allowing the states parties to decide which specific mode of dispute settlement they prefer. By providing flexibility on various fronts, the MIDSI Agreement would permit the proponents of various models to participate in the creation of a single institutional framework for the settlement of investment disputes, while safeguarding their freedom to choose the approach to adjudication that best matches their preferences. In our view, such a model would be preferable to the current, fully fragmented institutional framework. While it would incorporate many of the sources of inconsistency and incoherence that currently affect international investment law, it would also create the means for the progressive reduction of existing inconsistencies. The existence of a multilateral institutional framework would permit integrating the current fragmented legal landscape in one institutional setting, which would provide mechanisms for further progressive defragmentation.

\section{Elements of Defragmentation in MIDSI's Design: the Multilateral Investment Court}

As sketched out above, the MIDsi Agreement would permit parties to refer investment disputes to different types of adjudicators, which would operate,

\footnotetext{
$5^{8}$ See Nish Shetty and Romesh Weeramantry, "India's New Approach to Investment Treaties", 18 Asian Dispute Review (2016), 189.

59 Comprehensive and Progressive Trans-Pacific Partnership, Article 9.29(1); Comprehensive Economic and Trade Agreement, signed 30 October 2016, entered into force provisionally on 21 September 2017, Article 8.39(1).
} 
however, under the umbrella of one multilateral institution. The resulting flexibility, in turn, raises the question whether the resulting system would not contribute to further fragmentation, as is already the case under present-day investor-state arbitration. To reduce the risk of fragmentation, several design features developed on the basis of comparative institutional design analysis could be integrated into the institutional framework offered by MIDSI.

In particular, the MIC, as one of MIDsI's adjudicatory pillars whose composition is legitimated by MIDsI's assembly of states parties, could be designed to serve as a centripetal force to reduce the negative consequences of fragmentation that arise out of the flexibility in investment dispute settlement under the umbrella of MIDSI. The MIC could do so through a variety of system-wide competences that MIDSI's members can decide whether or not to opt into. These competences range from (a) the MIC serving as a reviewing body for decisions by (inter-state and investor-state) arbitral tribunals, at one end of the spectrum (see Section 4.1), via (b) competences for advisory opinions and preliminary ruling requests (see Section 4.2), to (c) purely auxiliary, but systemwide competences, in particular the granting of provisional measures and the power to decide on challenges to arbitrators (see Section 4.3).

\subsection{The MIC as a Reviewing Body: Appeals and Annulment}

In principle, different adjudicators that apply the same set of common principles, which in the case of international investment law consist of recurring standards of treatment and investment protection and standard definitions across the universe of bilateral, regional, and sectoral IIAs, ${ }^{60}$ may attain a certain level of coherence by taking into account and building on each other's decisions. This has been the case, to a considerable extent, in the traditional system of investor-state arbitration, which has developed into a system of de facto precedent. ${ }^{61}$ It has also been the case in other fields of international law where dispute settlement is not centralized. Thus, in the first case concerning maritime delimitation before IT LOs, the Tribunal had regard to, and followed, the jurisprudence on the matter that had emerged in ICJ adjudication and interstate arbitration. Judge Tullio Treves noted that "decisions by different courts and tribunals on the same law may be a source of richness and not of contradiction," as long as these courts and tribunals see themselves as participating

6o For the argument that international investment law is built on multilateral structures and that investment treaties contain shared norms, see Schill, supra note 12.

$61 \quad$ Ibid., 321-357. 
in "a collective interpretative endeavor ... keeping in mind the need to ensure consistency and coherence," while adding their own contributions. ${ }^{62}$

The approach of seeing adjudication as a "collective interpretative endeavor" may operate well when cases are few and far apart, allowing each adjudicator to take stock of the case law and seek harmony among the different standards. In contemporary investment law, however, the sheer number of disputes running in parallel makes ensuring consistency and coherence a formidable challenge even for those arbitral tribunals that actively seek to contribute to a harmonious development of the law governing international investment relations. ${ }^{63}$ Appropriate design of dispute settlement institutions may provide mechanisms of defragmentation that can contribute to ensuring a higher degree of interpretative coherence even if different types of adjudicators are involved in resolving investment disputes as part of the flexible architecture of MIDSI we outlined above.

To start with, if the MIC as one pillar of investment dispute settlement under MIDSI is designed as a permanent institution composed of judges with fixed terms, it is more likely to develop a coherent jurisprudence on norms that are shared throughout the universe of IIAs and in investment dispute settlement than tribunals (both inter-state and investor-state) operating ad hoc and independently from each other, even if their activity is administered under the umbrella of MIDSI. A certain degree of coherence in the application of the principles governing international investment relations can be attained if the MIC is itself selected by the states in question as the mode of dispute settlement under MIDSI. But the same is true if it is empowered to review, as an annulment or appeals body, legal interpretations developed by arbitral tribunals operating under one of the other pillars of MIDSI.

The deepest form of review the MIC could exercise is appeal. ${ }^{64}$ The WTO Appellate Body has, by reviewing legal interpretations developed by panels, established a high degree of consistency in the interpretation of the different

62 Dispute Concerning Delimitation of the Maritime Boundary Between Bangladesh and Myanmar in the Bay of Bengal (Bangladesh/Myanmar), ITLos Case No. 16, Judgment (14 March 2012), Declaration of Judge Tullio Treves, p. 141. Judge Rüdiger Wolfrum went a step further, arguing that UNCLOS "requires [courts and tribunals applying it] to harmonize their jurisprudence with the view to avoiding any fragmentation" (ibid., Declaration of Judge Wolfrum, pp. 136, 137).

63 See Jürgen Kurtz, "Building Legitimacy Through Interpretation in Investor-State Arbitration: On Consistency, Coherence and the Identification of Applicable Law", in Zachary Douglas, Joost Pauwelyn and Jorge Viñuales (eds.), The Foundations of International Investment Law: Bridging Theory into Practice (OUP, 2014), 257.

64 Christoph Schreuer, "From ICSID Annulment to Appeal Half Way Down the Slippery Slope", 10 Law and Practice of International Courts and Tribunals (2011), 211. 
provisions of wто law and developed a generally coherent set of legal tests to determine compliance with WTO rules. ${ }^{65}$ Even if the outcome of a dispute cannot be fully predicted, once the Appellate Body has pronounced on an issue, the key legal standards that subsequent panels and the Appellate Body will apply become highly predictable. The coherence among Appellate Body reports is due in part to an institutional design the Appellate Body itself has promoted. The "collegiality" rule, according to which the seven Appellate Body Members exchange views prior to the issuing of reports, ${ }^{66}$ and its demand that WTO panels follow its interpretations in subsequent disputes, unless they have "cogent reasons" to take a different path, ${ }^{67}$ have in fact led to claims that the Appellate Body has promoted a level of coherence that goes beyond that intended by што Members, which would have preferred each wто panel to make its own assessment of the dispute before it. ${ }^{68}$

States wary of an excessive centralizing role for the MIC may choose not to task it with hearing appeals, but rather with hearing requests for annulment of arbitral awards; states could, in other words, tailor the type of review the MIC is to engage in whenever disputes involving them are concerned. In order to determine the standards of review to be applied by the MIC sitting in annulment of arbitral awards, rather than acting as a full-fledged instance of appeal, parties could draw inspiration from the powers given to Annulment Committees under the ICSID Convention. These are limited to annulling awards in which a tribunal has gone beyond its powers and function, or violated fundamental rules of procedure, and not cases in which it has merely adopted interpretations of the governing law with which the Committee disagrees. ${ }^{69}$ In order to have its award annulled, a properly constituted tribunal must, inter alia, have "manifestly exceeded its powers", "serious[ly] depart[ed] from a fundamental rule of procedure", or "failed to state the reasons" for its decisions. ${ }^{70}$

65 Robert Howse, "The World Trade Organization 20 Years On: Global Governance by Judiciary", 27 European Journal of International Law (2016), 9.

66 WTO, Working Procedures for Appellate Review, 16 August 2010 (WT/AB/WP/6), para. 4.

67 Appellate Body Report, US - Stainless Steel (Mexico), adopted 20 May 2008 (WT/DS344/ $\mathrm{AB} / \mathrm{R})$, paras. 304-313. $^{2}$

68 See e.g. U.S. Statements Delivered by Ambassador Dennis Shea at the WTO General Council Meeting (Geneva, 7 May 2019), https://geneva.usmission.gov/2019/05/08/ambassador -sheas-statement-at-the-wto-general-council-meeting-agenda-items-4-6-7/, accessed 10 May 2019.

69 See Giorgio Sacerdoti, "Precedent in the Settlement of International Economic Disputes: The WTO and Investment Arbitration Models", in Arthur Rovine (ed.), Contemporary Issues in International Arbitration and Mediation: The Fordham Papers (Martinus Nijhoff, 2010), $225^{-246 .}$

$70 \quad$ ICSID Convention, Article 52(1). 
While a similarly limited standard of review would make it more difficult for the MIC to promote consistency in interpretations, if this feature is combined with other institutional features explored below that would permit system-wide interpretations - such as binding MIC Opinions or binding interpretations of the MIDSI Agreement - arbitral awards that fail to apply these system-wide interpretations could be seen as departing from a "fundamental rule of procedure", thus requiring arbitral tribunals to follow binding interpretations of norms and principles that are shared across international investment law.

\subsection{AdvisoryJurisdiction and Preliminary Rulings}

Independently of whether the MIC would have review powers over tribunals' awards, the MIC could also perform a defragmenting role through other procedural arrangements that are known from other international dispute settlement systems. One could consider establishing, in the relations between arbitral tribunals that settle investment disputes and the MIC, a procedure that is similar to the requests for preliminary rulings that domestic courts in the EU can make to the Court of Justice of the European Union (CJEU) in order to ensure the uniform interpretation of EU law. ${ }^{71}$ The preliminary ruling mechanisms may apply even when the main dispute is settled by a nonEU body. ${ }^{72}$ Under the EU-Ukraine Association Agreement, for example, an inter-party arbitration panel faced with a question of interpretation of EU law is prohibited from interpreting EU rules itself and required to "request the Court of Justice of the European Union to give a ruling on the question."73 The CJEu's preliminary ruling is then binding on the domestic court or arbitral panel.

71 Treaty on the Functioning of the European Union, OJ C 326/47, 26 October 2012, Article 267. See Clifford J. Carrubba and Lacey Murrah, "Legal Integration and Use of the Preliminary Ruling Process in the European Union", 59 International Organization (2005), 399 (assessing the practice of using the preliminary ruling procedure to assert EU rights).

72 See Jacopo Alberti, "New Developments in the EU System of Judicial Protection: The Creation of the Unified Patent Court and Its Future Relations with the CJEU", 24 Maastricht Journal of European and Comparative Law (2017), 6 (noting the ability of the projected Unified Patent Court to request from the CJEU preliminary rulings on matters of EU law); Jürgen Basedow, "EU Law in International Arbitration: Referrals to the European Court of Justice", 32 Journal of International Arbitration (2015), 367, 380 (concluding that an ISDS adjudicator "appears qualified" to submit to the CJEU requests for preliminary rulings); Gijs Verhagen, "The Compliance and Dispute Settlement System of the European Energy Community", 46 Legal Issues of Economic Integration (2019), 149.

EU-Ukraine Association Agreement, OJ L 161/3, 29 May 2014, Article 322(2). 
A similar system of requests for preliminary rulings has been considered already by other scholars in the context of investment arbitrations ${ }^{74}$ and could be made part of the MIC's competences in order to ensure interpretative coherence. Such requests could relate to common procedural norms that all modes of dispute settlement under MIDSI share, such as rules on transparency, thirdparty participation, the taking of evidence, etc., but also to the interpretation of substantive norms, such as the principles of international investment law that appear in virtually all IIAs in a similar, and at times even identical, fashion. The MIDSI Agreement could establish, for example, that in case of disagreement among arbitrators on questions of legal interpretation of shared norms, or in case an arbitral tribunal concludes that it should adopt an interpretation of a shared norm that is substantially different from that adopted by another tribunal, any of the arbitrators may refer the question to the MIC for a preliminary ruling. The MIC's ruling could then bind the tribunal that asked the question. State parties could also determine whether the ruling would subsequently bind other tribunals or whether it would stand as an authoritative, but non-binding, interpretation.

Another possibility would be for the MIC to be empowered to provide binding interpretations of the shared norms applicable to investment disputes outside the context of contentious disputes. This could be done through the instrument of judicial opinions, such as those issued by the ICJ, ITLOS, or the CJEU. Opinions can be advisory, as they are in the ICJ and ITLOS systems, meaning that they would be authoritative without being binding. ${ }^{75}$ But they can also be binding, as they are in the EU system, requiring subsequent tribunals to follow and apply them, with contradiction being a possible ground for annulment or appeal. ${ }^{76}$ To prevent abuse of the instrument of opinions, the MIDSI Agreement could impose requirements as to who can request an Opinion, and under what circumstances. For example, it may require that twothirds of MIDsI's parties approve a request for an Opinion, or provide that

74 See Christoph Schreuer, "Preliminary Rulings in Investment Arbitration", in Karl P. Sauvant (ed.), Appeals Mechanism in International Investment Disputes (oup, 2008), 207; Katharina Diel-Gligor, Towards Consistency in International Investment Jurisprudence: A Preliminary Ruling System for ICSID Arbitration (Brill, 2017).

75 See Edvard Hambro, "The Authority of the Advisory Opinions of the International Court of Justice", 3 International \& Comparative Law Quarterly (1954), 2; Roberto Ago, "Binding' Advisory Opinions of the International Court of Justice", 85 American Journal of International Law (1991), 439 .

76 Miguel Poiares Maduro, "Interpreting European Law: Judicial Adjudication in a Context of Constitutional Pluralism", 1 European Journal of Legal Studies (2007), 137. 
Opinions may only be requested once a concrete divergence arises in the jurisprudence of different dispute settlement pillars of MIDSI.

\subsection{Provisional Measures and Challenges to Arbitrators}

The MIDSI Agreement may also take advantage of the MIC to perform system-wide functions to address procedural gaps that are inherent to a system in which arbitration will remain an important means of dispute settlement. While arbitration offers advantages in terms of flexibility, the need to constitute an arbitral tribunal for every dispute generates problems of two kinds. First, between the time a complaint is filed and the constitution of the tribunal no international adjudicator is in a position to act in order to preserve the rights and obligations of the parties by ordering interim measures. Second, in case there is a challenge to one or more arbitrators, the sole organ available to adjudicate on such challenges is either the arbitral tribunal itself or an appointing authority. In these cases, comparative institutional design analysis provides examples of how a standing institution may be used to address the issues arising in both situations.

With respect to provisional measures, if arbitration is the selected mode of dispute settlement of the parties involved, the MIDs I Agreement may task the MIC with considering requests for provisional measures pending the constitution of the arbitral tribunal. ${ }^{77}$ This would reproduce a mechanism found in UNCLOS, which endows adjudicators with prima facie jurisdiction to award provisional measures "to preserve the respective rights of the parties to the dispute". ${ }^{78}$ In case arbitration is the mode of adjudication selected (whether by choice or by default), UNCLOS empowers ITLOS to prescribe, modify, or revoke provisional measures if it considers that prima facie jurisdiction exists and "the urgency of the situation so requires". ${ }^{79}$ Once an arbitral tribunal is properly constituted, it may modify, revoke, or affirm these provisional measures. ${ }^{80}$ The MIC could be tasked with fulfilling the same function as ITLOS in the sense of having system-wide jurisdiction to order provisional measures pending the constitution of an investment tribunal.

\footnotetext{
77 See Cameron Miles, Provisional Measures Before International Courts and Tribunals (cuP, 2017).

78 UNCLOS, Article 290(1). The provision also permits provisional measures "to prevent serious harm to the marine environment".

79 UNCLOS, Article 290(5). Parties may agree on a different court or tribunal to issue provisional measures pending the constitution of the arbitral tribunal (ibid.).

80 See Rüdiger Wolfrum et al., "Provisional Measures of the International Tribunal for the Law of the Sea", 37 Indian Journal of International Law (1997), 429.
} 
Finally, the MIDSI Agreement may entrust the MIC with competence to oversee the proper constitution of arbitral tribunals by deciding on challenges to arbitrators for lack of the necessary qualifications, independence, and impartiality. Challenges in investment arbitration are currently addressed by different bodies, depending on the applicable arbitration rules. ${ }^{81}$ This raises issues of inconsistent standards being applied by different decision makers. Moreover, in the case of ICSID arbitrations, the remaining unchallenged members of the arbitral tribunal have to decide on the challenge, which could be seen as raising conflicts itself. Empowering the MIC to decide on challenges to arbitrators would allow for more consistency in controlling decision-makers' impartiality and independence and the application of shared norms on these matters across different pillars for investment dispute settlement under MIDSI.

In sum, the MIDSI Agreement may go beyond providing a single institutional framework for the settlement of investment disputes by different adjudicators. Contracting states to the envisaged MIDSI Agreement may take advantage of the MIC to provide it with system-wide competences to contribute to more consistency, coherence, and predictability in respect of shared norms in MIDSI dispute settlement, and to address gaps that cannot be satisfactorily solved within a purely arbitration-based dispute settlement mechanism.

\section{Comparative Institutional Design Analysis Beyond Adjudication}

So far, we have argued that the (still evolving) proposals for investment dispute settlement reform, as currently discussed in the context of UNCITRAL Working Group III, should not be produced from scratch, but build on experiences in other international dispute settlement contexts. We have shown that the underlying method of comparative institutional design analysis is a fruitful source for drawing inspiration in an exploratory fashion, for developing design features that combine flexibility in dispute settlement with elements that can help reduce jurisprudential cacophony and fragmentation and potentially contribute to further integration and convergence in the future. However, using comparative institutional design analysis does not need to be limited to questions of dispute settlement; it can also be used to support adding non-dispute settlement-related features to MIDSI that help address broader concerns

81 See Federica Cristani, "Challenge and Disqualification of Arbitrators in International Investment Arbitration: An Overview", 13 Law and Practice of International Courts and Tribunals (2014), 153; Baiju S. Vasani and Shaun A. Palmer, "Challenge and Disqualification of Arbitrators at ICSID: A New Dawn?”, 30 ICSID Review (2014), 1. 
in international investment governance. Four subject areas help to illustrate this point: (a) the integration of alternative dispute resolution mechanisms (see Section 5.1); (b) technical assistance, dispute avoidance, and prevention (see Section 5.2); (c) legal aid (see Section 5.3); and (d) negotiation of new investment rules (see Section 5.4).

\subsection{Alternative Dispute Resolution: Conciliation and Mediation}

Much of the current debate on ISDS reform has focused on the institutional setting of adversarial dispute settlement through different forms of adjudication. Less attention is afforded to the area of consensual dispute resolution, in particular investor-state conciliation or mediation. ${ }^{82}$ At the same time, many, if not most, recently concluded IIAs, as well as the main models for investment dispute settlement currently floated, integrate elements of consensual dispute settlement as a prerequisite before recourse can be had to investment adjudication. ${ }^{83}$

Comparative analysis provides for various examples where mechanisms for formal adjudication are combined with informal, consensual forms of dispute settlement and are partly even administered by the very same institution. ${ }^{84}$ The prime example is, of course, the ICsid Convention, which provides rules not only for investor-state arbitration, ${ }^{85}$ but also for the administration of conciliation proceedings. ${ }^{86}$ The ICSID Additional Facility further adds the possibility of limiting proceedings administered by ICSID to fact-finding, ${ }^{87}$ another form of settling international disputes peacefully, as provided for in Article 33 of the

82 There is, however, growing interest in scholarship and practice. See, for example, JackJ.Coe, "Toward a Complementary Use of Conciliation in Investor-State Disputes - A Preliminary Sketch", 12 UC Davis J. Int'l L. \& Pol'y (2005), 7; see also the contributions on investorstate mediation in 29 ICSID Review (2014), 1-141; International Energy Charter, Guide on Investment Mediation (2016), https://www.energycharter.org/fileadmin/Documents Media/CCDECS/2016/CCDEC201612.pdf, accessed 10 May 2019.

83 See Schill and Vidigal, supra note 10, 6-7.

84 Susan D. Franck, "Using Investor-State Mediation Rules to Promote Conflict Management: An Introductory Guide", 29 ICSID Review (2014), 66.

85 See ICSID Convention, Articles $36-55$. See further Rules of Procedure for Arbitration Proceedings (Arbitration Rules) (effective from to April 2006), https://icsid.worldbank .org/en/Documents/resources/2006\%20CRR_English-final.pdf, accessed 10 May 2019.

86 See ICsID Convention, Articles 28-35. See further the Rules of Procedure for Conciliation Proceedings (Conciliation Rules) (effective from 10 April 2006), https://icsid.worldbank .org/en/Documents/resources/2006\%20CRR_English-final.pdf, accessed 1o May 2019.

87 Article 2(c) of the Rules Governing the Additional Facility for the Administration of Proceedings by the Secretariat of the International Centre for Settlement of Investment Disputes (Additional Facility Rules), Doc. ICSID/11 (10 April 2006). See further Schedule A - Fact-Finding (Additional Facility) Rules. 
UN Charter ${ }^{88}$ MIDsI could equally be used to administer and help facilitate conciliation, mediation, or fact-finding proceedings for investment disputes, including by maintaining lists of individuals qualified to conduct such proceedings and by supporting such proceedings with qualified secretarial staff.

Comparative institutional design analysis would support the idea that the dispute settlement procedures available under MIDSI are not limited to formal adjudication. Instead, flexibility in investment dispute settlement design should integrate informal, consensual means of dispute settlement as well.

\subsection{Technical Assistance, Dispute Avoidance, and Prevention}

Similar to integrating mechanisms that avoid formal adjudication of investment disputes, MIDSI could also be designed so as to include organizational and procedural features that help avoid and prevent the coming into existence of formal disputes at an early stage. MIDSI could, for example, be designed so as to help host states minimize the risk of, or even avoid, liability under IIAs in the first place. This could address the fact that many problems attributed to ISDS have their origin elsewhere, including in deficient domestic institutions and their (administrative and judicial) procedures and in an insufficient implementation of substantive IIA disciplines. ${ }^{89}$ Hence, work on strengthening domestic governance and domestic institutions in order to reduce, if not avoid, the liability risk under IIAs, and to increase compliance of host states with their treaty obligations, would also address concerns towards ISDS by avoiding that disputes ensue in the first place. This is all the more true as breaches of IIAs often stem from acts of the executive branch of government, not the legislator or domestic courts.

One way for MIDSI to address these matters is to equip it with an organizational unit that is not involved in investment dispute settlement, but that provides technical assistance to host states in order to help them strengthen compliance with IIA commitments and avoid formal disputes from the very start. This could be achieved through legal advice, capacity-building, or training of domestic decision-makers on investment treaty compliance, dispute prevention, and the implementation of better conflict management strategies for host states facing ISDS claims. Assistance could also extend to helping host states conduct IIA impact assessments for certain measures in order to

88 See United Nations General Assembly Resolution 46/59, "Declaration on Fact-Finding by the United Nations in the Field of the Maintenance of International Peace and Security", UN Doc. No. A/RES/46/59 (9 December 1991).

89 For an in-depth study on the relationship between IIAs and domestic governance, see Mavluda Sattorova, The Impact of Investment Treaty Law on Host States: Enabling Good Governance? (Hart, 2018). 
prevent IIA disputes from arising in the first place. Technical assistance could even relate more generally to enhancing the domestic investment environment, including the quality of domestic institutions and the domestic legal framework governing foreign investment projects.

The idea of combining adjudication with legal advice or technical assistance could draw on the example of the Council of Europe, which provides, in addition to the adjudication of human rights disputes before the European Court of Human Rights, advice to member governments on the implementation of human rights and other international obligations, inter alia, through expert committees. ${ }^{90}$ Similarly, in the context of the WTO, besides technical assistance offered by the organization itself, a separate international organization - the Advisory Centre for WTO Law (ACWL) $)^{91}$ - provides legal assistance to developing and least-developed wто Members not only in disputes, but also during the regular operation of government, in examining the WTO-compatibility of governmental measures of these Members before they are enacted.

Comparative institutional design analysis would lend support to the idea of complementing MIDsI's adjudicatory mechanism with an advisory function that helps implement the international rule of law domestically, avoid friction in investor-state relations, and better achieve the objectives of modern international investment law, namely to promote sustainable investment and development.

\subsection{Legal Aid}

Technical assistance does not need to be limited to IIA implementation, domestic law reform, or the phase of prevention and management of disputes before contentious proceedings start. It can also extend to providing legal aid in contentious investment proceedings, in particular to actors that are in need of financial assistance in order to have access to MIDsI's dispute settlement procedures, including least developed countries, but also small and mediumsized investors, or even certain third parties. Here again, in developing institutional features of MIDSI one could draw on the example of the ACWL, which

9o See Jörg Polakiewicz, "Council of Europe (COE)", in Rüdiger Wolfrum (ed.), Max Planck Encyclopedia of Public International Law (online edition) (updated January 2019), paras. 14 and 32, www.mpepil.com, accessed 23 October 2019.

91 Agreement Establishing the Advisory Centre on wTо Law, adopted 30 November 1999, entered into force 15 July 2001, 2299 UNTS 249. See Chad P. Bown and Rachel McCulloch, "Developing Countries, Dispute Settlement, and the Advisory Centre on WTO Law", 19 Journal of International Trade \& Economic Development (2010), 33. 
provides legal advice on wTO dispute settlement proceedings for developing and least-developed Members. ${ }^{92}$

Similar to the ACWL, the body providing such aid would need to be separated from MIDSI's secretarial support for adjudicators. This is important both to safeguard the independence and impartiality of MIDSI's dispute settlement function, and also to ensure the right of parties to be represented by independent counsel. This notwithstanding, a legal aid unit could well be integrated under the umbrella of MIDSI as an overarching institution addressing international investment governance and investment dispute settlement, just as the defence in international criminal proceedings before the International Criminal Court (ICC) receives assistance from the ICC's Registry ${ }^{93}$ Again, comparative institutional design analysis would support integrating mechanisms for legal aid in investment dispute settlement through appropriate institutional solutions in MIDSI.

\subsection{Negotiation of Future Investment Rules}

Finally, MIDSI could also serve, in the form of its assembly of states parties, as a forum for the negotiation of future investment rules. While at the outset it could be expected that the law applicable to investment disputes would remain rather fragmented, consisting of a combination of domestic law and a multitude of IIAs, over time states could use MIDSI to collectively develop new investment rules, principally in the form of new agreements. ${ }^{94}$ This would help address the fact that one reason for the lack of coherence in the field stems from the fragmentation of the governing law into a large number of IIAs. Agreeing on uniform standards would, without a doubt, further increase consistency, coherence, and predictability. Having an inter-governmental forum, or platform, where such issues are regularly discussed, would be the first step towards the development of multilateral rules governing the substance of

$92 \quad$ For a detailed analysis of how the ACWL can provide a model for legal aid in investment dispute settlement, see Robert W. Schwieder, "Legal Aid and Investment Treaty Disputes: Lessons Learned from the Advisory Centre on WTO Law and Investment Experiences", 19 Journal of World Investment \& Trade (2018), 628. For further ways on how the procedure in investment dispute settlement can be adapted to help less affluent parties, see Kristen E. Boon, "Investment Treaty Arbitration: Making a Place for Small Claims", 18 Journal of World Investment \& Trade (2018), 667.

93 For an overview of the support provided by the ICC to the defence, see ICC, "Defence", www.icc-cpi.int/about/defence, accessed 24 April 2019.

94 See José E. Alvarez, International Organizations as Law-Makers (oup, 2005), esp. Chapter 5 ("International Organizations as Treaty-Makers", pointing out that international organizations centralize treaty-making, facilitating input from smaller states and non-governmental organizations). 
international investment relations. These rules could address, for example, standards of investment protection, but also investor obligations and responsible business conduct.

One example of an institution that combines international dispute settlement and a forum for negotiation of new rules is, of course, the WTO. Apart from the Dispute Settlement Body, it provides a forum for members to negotiate on a continuous basis new trade rules and agreements. ${ }^{95}$ Despite the difficulties with completing its most recent round of negotiations (the Doha Round) ${ }^{96}$ with a comprehensive set of new agreements, WTO Members have been able to reach a new agreement - the Trade Facilitation Agreement ${ }^{97}$ - as well as a number of other specific understandings, declarations, and decisions. ${ }^{98}$

Similarly to the WTO, MIDSI could include a body that is able to centralize negotiations of new agreements addressing international investment relations. This example illustrates how comparative institutional design analysis can help develop design features of MIDSI that cover not only international adjudication and international administration, but also areas of future international legislation in the field of international investment relations.

\section{Conclusion}

A key challenge in reforming investment dispute settlement is to prevent the divergent models and proposals currently being floated from leading to an institutionally fragmented system that lacks the institutional ability to minimize fragmentation and enhance consistency, coherence, and predictability. The establishment of MIDSI would address that risk. It would provide a solution to channel disagreements of states on dispute settlement design into the establishment of an institutional framework, namely a single multilateral institution, within which participants can agree to disagree and make use of their

95 On the effects of the Wто on trade negotiations, see Kyle Bagwell and Robert W. Staiger, "Multilateral Trade Negotiations, Bilateral Opportunism and the Rules of GATT/WTO", 63 Journal of International Economics (2004), 1.

96 See Robert Wolfe, “First Diagnose, Then Treat: What Ails the Doha Round?", 14 World Trade Review (2015), 7.

97 Agreement on Trade Facilitation, WT/MIN(13)/36, adopted 7 December 2013, entered into force 22 February 2017.

98 Decision of the General Council on the Amendment of the TRIPS Agreement, WT/L.641 (6 December 2005); Ministerial Decision on Duty-Free and Quota-Free Market Access for Least Developed Countries, WT/MIN(13)/45, 7 December 2013; Ministerial Decision on Export Competition, WT/MIN(15)/45 (21 December 2015); Ministerial Decision on Public Stockholding for Food Security Purposes, WT/MIN(15)/44 (21 December 2015). 
preferred mode of dispute settlement, but still provide for mechanisms that allow members to cooperate multilaterally both in respect of the settlement of investment disputes and potentially in shaping the future of the international investment regime also on substance.

Such an institutional framework could not only help promote convergence in the procedural law applicable to dispute settlement, which would arguably converge in a number of structural features independently of the mode of adjudication chosen, for example in respect of questions of transparency and third-party participation, the taking of evidence, or third-party funding, but could provide states with a long-term tool for building a comprehensive investment governance system that could tackle questions of substantive law as well.

The method we have employed to develop the underlying design features of such an institution is termed comparative institutional design analysis. This method consists of drawing inspiration, in an exploratory fashion, from the dispute settlement design of other international dispute settlement systems and exploring their use in the context of investment dispute settlement. What certainly is important, in this context, is also to remain wary of the context in which the design features of other international dispute settlement institutions develop.

Certainly, many salient questions relating to the creation of MIDSI remain open and must be addressed. Political feasibility will depend, of course, on the extent to which states are willing to engage in a multilateral reform process. Submissions made by various states to UNCITRAL Working Group III represent an encouraging signal in this respect. Additionally, the acceptance by the CJEU of the EU's participation in international mechanisms for the adjudication of investment disputes, ${ }^{99}$ combined with the EU's efforts towards establishing a MIC, greatly increase the likelihood that some form of multilateral institution will emerge over the coming years. The MIDSI proposal aims to insert this court into a broader framework that may be acceptable even to states with different preferences on dispute settlement that would not accept participating fully in the MIC. We hope not only that it would permit the establishment of a truly multilateral institution for investment dispute settlement, but also that it would provide a common structure for negotiations of a comprehensive future investment regime.

MIDSI's democratic legitimacy and institutional control mechanisms, its relationship to existing dispute settlement mechanisms in the field, in particular ICSID and the Permanent Court of Arbitration, and the question of trust of

99 CJEU, Opinion 1/17, Comprehensive Economic and Trade Agreement, 30 April 2019, ECLI:EU:C:2019:341. 
disputing parties, are just some of the challenges to be addressed. Similarly, there are many details to address once one moves beyond the structural questions of institutional design, including funding of the institution, its location, costs of proceedings, etc.

In respect of all of these issues, an important step forward, in our view, is to operate with a method that allows participants to structure the debate, consider ideas for reform options, and permit a comparative assessment of these options. As we have shown using the example of MIDSI, comparative institutional design analysis is such a method and can facilitate the debates about investment dispute settlement reform at UNCITRAL in order to result in a multilaterally agreeable outcome. 